\title{
Excitation-Contraction Coupling and Excitation-Transcription Coupling in Blood Vessels: Their Possible Interactions in Hypertensive Vascular Remodeling
}

\author{
E. MISÁRKOVÁ ${ }^{1}$, M. BEHULIAK ${ }^{1}$, M. BENCZE ${ }^{1}$, J. ZICHA ${ }^{1}$ \\ ${ }^{1}$ Institute of Physiology, Czech Academy of Sciences, Prague, Czech Republic
}

Received February 3, 2016

Accepted March 17, 2016

\begin{abstract}
Summary
Vascular smooth muscle cells (VSMC) display considerable phenotype plasticity which can be studied in vivo on vascular remodeling which occurs during acute or chronic vascular injury. In differentiated cells, which represent contractile phenotype, there are characteristic rapid transient changes of intracellular $\mathrm{Ca}^{2+}$ concentration $([\mathrm{Ca} 2+] \mathrm{i})$, while the resting cytosolic $\left[\mathrm{Ca}^{2+}\right] \mathrm{i}$ concentration is low. It is mainly caused by two components of the $\mathrm{Ca}^{2+}$ signaling pathways: $\mathrm{Ca}^{2+}$ entry via L-type voltagedependent $\mathrm{Ca}^{2+}$ channels and dynamic involvement of intracellular stores. Proliferative VSMC phenotype is characterized by long-lasting $\left[\mathrm{Ca}^{2+}\right] \mathrm{i}$ oscillations accompanied by sustained elevation of basal $\left[\mathrm{Ca}^{2+}\right]$ i. During the switch from contractile to proliferative phenotype there is a general transition from voltagedependent $\mathrm{Ca}^{2+}$ entry to voltage-independent $\mathrm{Ca}^{2+}$ entry into the cell. These changes are due to the altered gene expression which is dependent on specific transcription factors activated by various stimuli. It is an open question whether abnormal VSMC phenotype reported in rats with genetic hypertension (such as spontaneously hypertensive rats) might be partially caused by a shift from contractile to proliferative VSMC phenotype.
\end{abstract}

\section{Key words}

Vascular smooth muscle cells - Contractile VSMC phenotype • Proliferative VSMC phenotype $\bullet$ Cell $\mathrm{Ca}^{2+}$ handling $\bullet$ Intracellular signaling pathways

\section{Corresponding author}

J. Zicha, Institute of Physiology, Czech Academy of Sciences, Vídeňská 1083, 14220 Prague 4, Czech Republic. E-mail: zicha@biomed.cas.cz

\section{Introduction}

Basic function of fully differentiated vascular smooth muscle cells (VSMC) is their contraction for which they express a wide range of contractile and regulatory proteins. VSMC display a considerable plasticity of their phenotype. Under certain conditions such as vascular injury, atherosclerosis or hypertension the fully differentiated cells are able to undergo the process of partial dedifferentiation and to restart the program of cell growth and proliferation. Proliferating VSMC play an important role in the development of blood vessels or in the repair of damaged vessels because they are able to proliferate, to migrate and to synthesize the components of extracellular matrix.

Gary K. Owens has paid a considerable attention to hypertrophy, hyperploidy and hyperplasia of vascular smooth muscle in various forms of experimental hypertension (Owens and Schwartz 1982, Owens and Schwartz 1983). He suggested that VSMC hypertrophy represents an increase of tissue mass that is able to match increased functional demands without the loss of differentiated function. On the contrary, VSMC proliferation is associated with a temporary decrease in expression of smooth muscle-specific contractile proteins (Owens et al. 1986, Clowes et al. 1989). Thus proliferative VSMC growth may occur under pathological conditions or under the circumstances where functional demands exceed VSMC capacity to respond through cellular hypertrophy (Owens 1989). Numerous growth factors (including angiotensin II, vasopressin and 
endothelin-1), neurotransmitters, mechanical forces and extracellular matrix components (metalloproteinases) can affect the degree of VSMC differentiation and/or induce VSMC growth (with different contribution of hypertrophy and hyperplasia) (Owens 1995, Owens et al. 1996). The importance of cooperative interactions between multiple CArG elements (10-bp elements with a sequence $\left.\mathrm{CC}(\mathrm{A} / \mathrm{T})_{6} \mathrm{GG}\right)$ and serum response factor (SRF) and SRF-accessory proteins (such as myocardin) was summarized by Owens et al. (2004) who also reviewed the influence of particular growth factors (angiotensin II, platelet-derived growth factor-BB or transforming growth factor $\beta 1$ ) on CArG-mediated mechanisms controlling the expression of smooth muscle-specific differentiation marker genes.

Transition of contractile to proliferative VSMC phenotype is associated with the changes in the expression of ion channels, transporters, receptors and contractile proteins (Matchkov et al. 2012). These changes in gene expression lead to the alterations in $\mathrm{Ca}^{2+}$ signaling and vascular contractility (Vallot et al. 2000). The changes in intracellular cytosolic calcium concentration $\left[\mathrm{Ca}^{2+}\right]_{\mathrm{i}}$ in differentiated VSMC are large, short-term and locally limited whereas those seen in proliferating VSMC are small, slow and long-lasting. VSMC dedifferentiation is associated with mild elevation of both basal $\left[\mathrm{Ca}^{2+}\right]_{\mathrm{i}}$ and $\mathrm{Ca}^{2+}$ concentration in internal calcium stores (Munoz et al. 2013). These two different types (long-lasting and shortterm) of $\mathrm{Ca}^{2+}$ signaling influence $\mathrm{Ca}^{2+}$-dependent transcription factors and the expression of various genes required for a given state of the cell (Lipskaia and Lompre 2004, Berra-Romani et al. 2008).

Aortic VSMC from spontaneously hypertensive rats (SHR) are characterized by a partial shift from a contractile to a proliferative phenotype as indicated by lower levels of contractile-type smooth muscle myosin heavy chain (SM2) and by higher levels of proliferative (synthetic)-type smooth muscle myosin heavy chain (NMHC-B/SMemb) compared to normotensive controls (Umemoto et al. 2006). However, the relationship of this VSMC phenotype change to the altered function of vascular smooth muscle in hypertension has not been studied in detail yet.

\section{Vascular remodeling}

Vascular remodeling, which occurs during chronic alterations in blood perfusion of vascular bed (Bakker et al. 2002) or during reparation of blood vessels following acute vascular injury (Bendeck et al. 1994), is an example of modulation of VSMC phenotype. In both cases VSMC phenotype is shifted from a contractile type to a proliferative one.

Vascular remodeling is an adaptive response of blood vessel to various stimuli involving mechanical force which is accompanied by enhanced cytokine secretion (Schober 2008). Progressive changes in vascular wall structure are induced by increased blood pressure (Chen et al. 2011) or stent insertion (Chaabane et al. 2013). Vascular wall remodeling involves the changes occurring in all three layers (intima, media and adventitia) of vascular wall (Tuttle et al. 2001), but our review is focused on the alterations of tunica media, i.e. VSMC.

Remodeling is generally considered to be based upon the reorganization of existing material (Epstein et al. 1994). Nevertheless, tunica media remodeling consists of migration, proliferation and apoptosis of VSMC (Buus et al. 2001). Several models can be used for the study of remodeling process. Thus, a long-term constriction of isolated arteries (Bakker et al. 2000) leads to actin polymerization together with inward remodeling (Staiculescu et al. 2013). Small GTPases from Rho GTPase family participate intensively in the remodeling of actin cytoskeleton (Burridge and Wennerberg 2004, Staiculescu et al. 2013). Both altered blood flow and long-term vasoconstriction cause vascular wall remodeling which is associated with inflammatory response characterized by macrophage participation and increased expression of pro- and anti-inflammatory cytokines. This inflammatory response enhances remodeling process (Bakker et al. 2008).

A moderate increase in shear stress is associated with increased phosphorylation of transcription factor c-Jun (Haas et al. 2007) which activates the transcription of matrix metalloproteinases induced by mechanical stress (Ispanovic et al. 2006). These metalloproteinases acting on extracellular matrix and on cell surface are also involved in vascular wall remodeling (Sho et al. 2002).

Neointimal formation induced by vascular injury and associated calcineurin expression are greater in spontaneously hypertensive rats (SHR) than in normotensive Wistar-Kyoto (WKY) rats (Takeda et al. 2008).

\section{Excitation-Contraction Coupling}

The stimulation of VSMC by vasoconstrictor agonist leads to the phosphorylation of $20 \mathrm{kDa}$ regulatory 
subunit of myosin light chain which increases myosin ATPase activity and enhances vascular contraction (for review see Somlyo and Somlyo 2003). Two counteracting proteins - myosin light chain kinase (MLCK) and myosin light chain phosphatase (MLCP) participate in the regulation of phosphorylated/ dephosphorylated state of the myosin light chain (for the scheme see Fig. 1). Thus, the increased levels of phosphorylated myosin light chain can be achieved by either augmented activation of MLCK via calciumcalmodulin action or by the inhibition of MLCP induced through PKC/CPI-17 and/or RhoA/Rho kinase pathways.

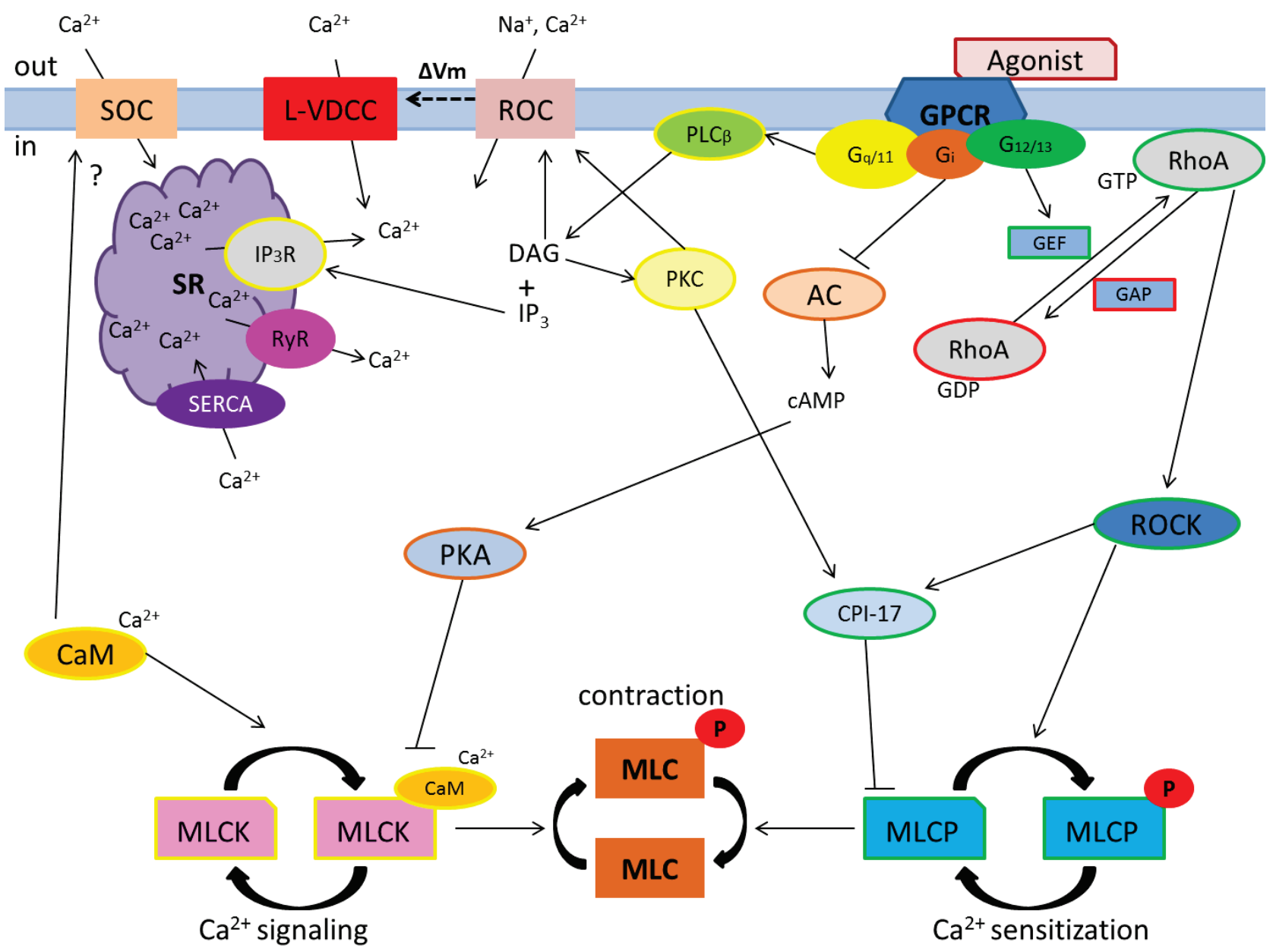

Fig. 1. Excitation-contraction coupling. Vasoconstrictors (such as norepinephrine, endothelin-1, angiotensin II) act via receptors coupled with $\mathrm{G}$ proteins (GPCR). Receptor stimulation leads to the activation of heterotrimeric $\mathrm{G}$ proteins which transmit the signal to the downstream cascade leading ultimately to VSMC contraction. There are three types of a subunits of $G$ proteins $-G_{q / 11}$ (yellow oval), $\mathrm{G}_{\mathrm{i}}$ (orange oval) and $\mathrm{G}_{12 / 13}$ (green oval). The pathway from $\mathrm{G}_{\mathrm{q} / 11}$ is generally referred as $\mathrm{Ca}^{2+}$ signaling while the pathway from $\mathrm{G}_{12 / 13}$ is considered as $\mathrm{Ca}^{2+}$ sensitization. $\mathrm{G}_{\mathrm{q} / 11}$ subunit activates phospholipase $\mathrm{C}_{\beta}\left(\mathrm{PLC}_{\beta}\right)$, which cleaves phosphatidyl inositol-4,5-bisphosphate to diacylglycerol (DAG), and inositol-1,4,5-trisphosphate $\left(\mathrm{IP}_{3}\right)$, which binds to inositol trisphosphate receptors $\left(\mathrm{IP}_{3} \mathrm{R}\right)$ on sarcoplasmic reticulum (SR), causing thus the rise of intracelullar $\mathrm{Ca}^{2+}$ concentration $\left[\mathrm{Ca}^{2+}\right]_{i}$. Diacylglycerol activates receptor-operated channels (ROC) and protein kinase $\mathrm{C}$ (PKC) which might also activate ROC. ROC enable $\mathrm{Na}^{+}$entry into the cell, leading thus to plasma membrane depolarization. This depolarization opens voltage-dependent $\mathrm{Ca}^{2+}$ channels (L-VDCC). $\mathrm{Ca}^{2+}$ is bound to calmodulin (CaM) which then activates myosin light chain kinase (MLCK). Phosphorylation of myosin light chain causes VSMC contraction. Calmodulin also activates store-operated $\mathrm{Ca}^{2+}$ channels (SOC) that are responsible for $\mathrm{Ca}^{2+}$ refilling of depleted sarcoplasmic reticulum. In the membrane of sarcoplasmic reticulum there are not only $\mathrm{IP}_{3} \mathrm{R}$ but also ryanodine receptors (RyR) which are activated by $\left[\mathrm{Ca}^{2+}\right]_{i}$ elevation and their activation leads to the depletion of $\mathrm{Ca}^{2+}$ stores in sarcoplasmic reticulum, and $\mathrm{Ca}^{2+}$ ATPase of sarcoplasmic reticulum (SERCA) which actively transfer $\mathrm{Ca}^{2+}$ from cytoplasm into sarcoplasmic reticulum. $\mathrm{G}_{i}$ subunit leads to VSMC contraction by the inhibition of adenylate cyclase (AC). Under the normal conditions CAMP is bound to protein kinase A (PKA) which desensitizes MLCK. G 12/13 $_{3}$ subunit activates guanine nucleotide exchange factor (GEF), which dissociates GDP from G protein RhoA and enables GTP binding on the place, where GDP was bound. RhoA-GTP activates Rho-kinase which phosphorylates and inactivates myosin light chain phosphatase (MLCP). Rho-kinase (ROCK) also phosphorylates CPI-17 and its phosphorylated form binds to the catalytic subunit of MLCP. Further abbreviations: $\triangle \mathrm{Vm}$ - membrane potential change; CPI-17 - smooth muscle-specific inhibitory protein of MLCP; GAP - GTPaseactivating protein; RhoA - GTPase of Ras homologue gene family. 
Calcium signaling in differentiated VSMC

In contractile cells $\left[\mathrm{Ca}^{2+}\right]_{\mathrm{i}}$ elevation activates MLCK via calcium-calmodulin (CaM) complex (Somlyo et al. 1999, Isotani et al. 2004). A subsequent phosphorylation of myosin light chain elicits VSMC contraction. $\mathrm{Ca}^{2+}$ entry into the cell is generally associated with the activation of $\mathrm{G}_{\mathrm{q} / 11}$ subunit of trimeric G protein. $\mathrm{G}_{\mathrm{q} / 11}$ activates phospholipase $\mathrm{C}_{\beta}\left(\mathrm{PLC}_{\beta}\right)$ which cleaves phosphatidylinositols into second messengers inositoltrisphosphate $\left(\mathrm{IP}_{3}\right)$ and diacylglycerol (DAG) $(\mathrm{Wu}$ et al. 1992). $\mathrm{IP}_{3}$ binds to its receptors in sarcoplasmic reticulum and releases $\mathrm{Ca}^{2+}$ from internal stores into cytosol (Berridge 1993). DAG activates receptoroperated channels (ROC) which seem to belong to the family of non-selective cationic channels (Albert and Large 2002) (see below). These events lead to membrane depolarization, opening of $\mathrm{L}$ type voltage-dependent $\mathrm{Ca}^{2+}$ channels (L-VDCC) and massive $\mathrm{Ca}^{2+}$ entry into the cell. $\mathrm{Ca}^{2+}$ is bound to $\mathrm{CaM}$ and this complex activates MLCK (Fig. 1). $\mathrm{Ca}^{2+}$ released from sarcoplasmic reticulum opens store-operated channels (SOC) which causes $\left[\mathrm{Ca}^{2+}\right]_{\mathrm{i}}$ increase through capacitative calcium entry (Smani et al. 2004). In parallel, high-conductance, $\mathrm{Ca}^{2+}$-dependent $\mathrm{K}^{+}$ channels are activated $\left(\mathrm{BK}_{\mathrm{Ca}}\right)$, leading to membrane hyperpolarization and closing of L-VDCC (Nelson et al. 1995). $\left[\mathrm{Ca}^{2+}\right]_{\mathrm{i}}$ level is further modulated by $\mathrm{Ca}^{2+}$-ATPases of sarcoplasmic reticulum or plasma membrane (SERCA and PMCA pumps, respectively) as well as by $\mathrm{Na}^{+} / \mathrm{Ca}^{2+}$ exchanger which all lower $\left[\mathrm{Ca}^{2+}\right]_{\mathrm{i}}$ (Berridge et al. 2003, Berra-Romani et al. 2008).

\section{Calcium channels in the plasma membrane}

In VSMC there are two important types of channels enabling $\mathrm{Ca}^{2+}$ entry into the cell. Voltagedependent and -independent channels transmit different $\mathrm{Ca}^{2+}$ signals which have a specific role in the regulation of gene expression and protein synthesis. During the dedifferentiation there is a general transition from voltage-dependent $\mathrm{Ca}^{2+}$ entry to voltage-independent $\mathrm{Ca}^{2+}$ entry into the cell (Bergdahl et al. 2005, Tai et al. 2009, Yu et al. 2003).

\section{Voltage-dependent $\mathrm{Ca}^{2+}$ channels}

Voltage-dependent $\mathrm{Ca}^{2+}$ channels of $\mathrm{L}$ type (L-VDCC) represent a major pathway for $\mathrm{Ca}^{2+}$ entry into differentiated VSMC. L-VDCC, which are activated by membrane depolarization, are characterized by a high conductance and a slow inactivation (Catterall 2000). $\mathrm{Ca}^{2+}$ entry through L-VDCC is essential for excitation- contraction coupling and thus for VSMC contraction. In addition, L-VDCC can also influence gene expression by the activation of $\mathrm{Ca}^{2+}$-dependent transcription factors (excitation-transcription coupling, see below). The number of functional L-VDCC on the cell surface is decreasing during cell dedifferentiation (Gollasch et al. 1998). There are several studies indicating that functional L-VDCC are closely associated with differentiated state of VSMC. The blockade of mitogen-activated protein kinase (MAPK) in proliferating VSMC increased the number of $\alpha_{1 C}$ pore-forming subunits of L-VDCC and functional L-VDCC (Ihara et al. 2002). MAPK is generally considered to be involved in growth, migration and proliferation of VSMC (Pulver-Kaste et al. 2006, Tokunou et al. 2001, Xi et al. 1999). The in vivo blockade of L-VDCC in mesenteric arteries by means of siRNA transfection led to increased basal $\left[\mathrm{Ca}^{2+}\right]_{\mathrm{i}}$ but reduced vascular contractility and to a decrease in the expression of contractile protein genes in VSMC (Kudryavtseva et al. 2014). A further VDCC type T-VDCC - was found to be expressed preferentially in S phase of cultured aortic VSMC (Kuga et al. 1996). T-VDCC are activated at low potential changes, have small conductance and are rapidly inactivated (PerezReyes 2003). Both T-VDCC and TRP channels may play an important role in $\mathrm{Ca}^{2+}$ entry into dedifferentiated VSMC.

Genetic hypertension in SHR is characterized by sympathetic hyperactivity (Head 1989, de Champlain 1990, Pintérová et al. 2011) and by augmented $\mathrm{Ca}^{2+}$ influx through L-VDCC (Hermsmeyer 1991, Ohya et al. 1998, Cox \& Rusch 2002, Sonkusare et al. 2006). L-VDCC are upregulated in SHR arteries (Pratt et al. 2002) and this upregulation was ascribed to high blood pressure and membrane depolarization (Pesic et al. 2004). Nevertheless, it should also be noted that L-VDCC in vascular smooth muscle are activated by norepinephrine (Nelson et al. 1988). This is in line with the fact that a great part of sympathetic vasoconstriction, which is augmented in SHR, is susceptible to the inhibition by nifedipine (Paulis et al. 2007, Pintérová et al. 2010, Zicha et al. 2014). Although the above findings support a major importance of sympathetic nervous system for the enhanced participation of L-VDCC in the maintenance of high blood pressure, the alterations in $\beta$-adrenergic or NO-dependent vasodilatation might also contribute to the enhanced $\mathrm{Ca}^{2+}$ influx in SHR because L-VDCC can be closed by elevated levels of cyclic nucleotides (both cAMP and cGMP) (Ishikawa et al. 1993, Orlov et al. 
1996, Liu et al. 1997, Lewis et al. 2005, Pintérová et al. 2009). Our recent studies revealed enhanced $\mathrm{Ca}^{2+}$ entry together with attenuated $\mathrm{Ca}^{2+}$ sensitization as characteristic hallmarks of genetic hypertension in SHR (Behuliak et al. 2013, 2015).

\section{Non-selective cationic channels}

TRP (transient receptor potential) channels in the membrane of VSMC form heterotetrameric cationic channels often permeable for $\mathrm{Ca}^{2+}$. TRP family also involves plasma membrane channels which are activated either by the depletion of internal $\mathrm{Ca}^{2+}$ stores (storeoperated channels, SOC) or by receptor agonists via intracellular ligands (receptor-operated channels, ROC). Among the components of SOC there are proteins of TRPC1 (Bergdahl et al. 2005) or other TRP subfamilies (Saleh et al. 2006) and probably also pore forming subunit (Orai) and stromal interaction molecule 1 (STIM1) which are involved in the control of SOC activity (Liao et al. 2007). Molecular candidates for ROC are mainly TRPC3 and TRPC6 channels (Berra-Romani et al. 2008). ROC are opened through a pathway that is independent on internal $\mathrm{Ca}^{2+}$ stores. The activation of G protein-coupled receptors (GPCR) by agonists leads to the formation of DAG which stimulates the activation of ROC by a pathway independent of protein kinase C (PKC) (Helliwell and Large 1997) or through its binding to PKC (Albert and Large 2002). The activation of SOC is dependent on internal $\mathrm{Ca}^{2+}$ stores and includes the enhanced production of $\mathrm{IP}_{3}$ which binds to $\mathrm{IP}_{3} \mathrm{R}$ and releases $\mathrm{Ca}^{2+}$ from sarcoplasmic reticulum. Subsequent $\left[\mathrm{Ca}^{2+}\right]_{i}$ elevation stimulates $\mathrm{CaM}$ to the activation of SOC (Smani et al. 2004). The increased expression of particular TRP channel isoforms and enhanced $\mathrm{Ca}^{2+}$ entry through SOC occur during blood vessel cultivation (Bergdahl et al. 2005, Yu et al. 2003). This might be due to a significant participation of STIM1 and Orai (Potier et al. 2009) which are almost absent in differentiated VSMC (Berra-Romani et al. 2008, Potier et al. 2009). STIM1 functions as $\mathrm{Ca}^{2+}$ sensor of sarcoplasmic reticulum. After the depletion of internal $\mathrm{Ca}^{2+}$ stores there is a relocalization of STIM1 in sarcoplasmic reticulum closer to the cytoplasmic membrane (Wu et al. 2006). Orai is a pore forming molecule which forms a cationic channel in plasma membrane. Decreased expression of these molecules leads to lower SOC activation (Potier et al. 2009). VSMC cultivation increases the expression of both STIM1 and Orai (Berra-Romani et al. 2008, Potier et al. 2009). During the cultivation there is also a change in SOC activation. Differentiated cells stimulate SOC more through ryanodine receptors (RyR) located on sarcoplasmic reticulum, while dedifferentiated cells lower the contribution of RyR and increase the contribution of $\mathrm{IP}_{3} \mathrm{R}$ to the activation of SOC (Berra-Romani et al. 2008). This is in agreement with a decreased expression of RyR in proliferating VSMC (Vallot et al. 2000). The transition from contractile to proliferative phenotype also substantially increases the activity of ROC (measured as $\mathrm{Ba}^{2+}$ entry after administration of permeable DAG analogue) (Berra-Romani et al. 2008). Dedifferentiated VSMC show a lower L-VDCC expression (Gollasch et al. 1998) so that ROC and SOC mediate a considerable part of $\mathrm{Ca}^{2+}$ entry in these cells.

SOC were reported to be exaggerated in preglomerular VSMC of SHR (Fellner and Arendhorst 2002). Capacitative $\mathrm{Ca}^{2+}$ entry was also found to be enhanced in SHR but no WKY mesenteric arteries subjected to chronic cyclic stretch (Lindsey and SonguMize 2010). The expression of Orail and STIM1 is increased in the aorta of stroke-prone SHR in which calcium release-activated calcium channels are highly activated, contributing thus to the abnormal vascular function in this rat strain (Giachini et al. 2009). STIM1/Orail pathway is more activated in the aorta of male than female stroke-prone SHR (Giachini et al. 2012). It should be noted that VSMC derived from the aorta of male SHR migrate and grow faster than those obtained from female SHR (Bačáková and Kuneš 2000).

There are several reports on the alterations of TRPC in arterial smooth muscle of hypertensive rats. The increased expression of TRPC3 channels has been repeatedly reported in SHR (Liu et al. 2009, Noorani et al. 2011, Adebiyi et al. 2012), but some investigators also observed increased expression of TRPC6 and TRPC1 channels in rats with genetic hypertension (Zulian et al. 2010, Lin et al. 2015). The relationship between TRPC3 or TPRPC6 channels and ROC-mediated calcium entry has been suggested in various forms of experimental hypertension (Liu et al. 2009, Pulina et al. 2010, Zulian et al. 2010). TRPC3 channels are also coupled to $\mathrm{IP}_{3}$ receptors on sarcoplasmic reticulum in mesenteric VSMC and this coupling is elevated in SHR (Adebiyi et al. 2012).

Calcium channels in the membrane of sarcoplasmic reticulum

Inositol trisphosphate receptors $\left(\mathrm{IP}_{3} \mathrm{R}\right)$ and ryanodine receptors (RyR) are intracelullar $\mathrm{Ca}^{2+}$ channels 
on the surface of sarcoplasmic reticulum. Both receptor families mediate calcium-induced calcium release (CICR) from sarcoplasmic reticulum which participates in the formation of $\mathrm{Ca}^{2+}$ sparks and regenerative $\mathrm{Ca}^{2+}$ waves (Berridge 1997). Another important property of $\mathrm{IP}_{3} \mathrm{R}$ and RyR is their dual sensitivity to $\mathrm{Ca}^{2+}$. The increase of cytosolic $\mathrm{Ca}^{2+}$ concentration initiates the development of positive feedback by opening the neighboring channels, leading thus to a further mobilization of $\mathrm{Ca}^{2+}$ from sarcoplasmic reticulum. If $\left[\mathrm{Ca}^{2+}\right]_{i}$ is elevated above certain levels, a negative feedback appears which closes these channels (Bootman and Berridge 1996). During VSMC dedifferentiation there is an increase of $\mathrm{IP}_{3} \mathrm{R}$ (Berra-Romani et al. 2008) which might lead not only to a further $\left[\mathrm{Ca}^{2+}\right]_{\mathrm{i}}$ elevation but also to the enhanced $\mathrm{Ca}^{2+}$ dependent SOC activation (Smani et al. 2004) and further $\left[\mathrm{Ca}^{2+}\right]_{\mathrm{i}}$ augmentation. $\mathrm{IP}_{3} \mathrm{R}$ activation is important for VSMC proliferation (Afroze et al. 2007, Wilkerson et al. 2006). The induction of proliferation by fetal bovine serum (FBS) or platelet-derived growth factor (PDGF) causes a reduction in the expression of RyR (Vallot et al. 2000) which are important for the activation of $\mathrm{BK}_{\mathrm{Ca}}$ and for closing L-VDCC due to hyperpolarization (Nelson $e t$ al. 1995). It is possible that lower RyR expression is related to a decreased L-VDCC expression found in dedifferentiated VSMC (Gollasch et al. 1998).

\section{$\mathrm{Ca}^{2+}$ ATPase of sarcoplasmic reticulum (SERCA)}

SERCA is a pump located in the membrane of sarcoplasmic reticulum of VSMC which is powered by ATP and transports $\mathrm{Ca}^{2+}$ from cytosol into the lumen of sarcoplasmic reticulum in order to maintain intracelullar $\mathrm{Ca}^{2+}$ homeostasis. Two variants of SERCA gene SERCA2 $a$ and SERCA2b - are expressed in VSMC (Lipskaia et al. 2014). SERCA2b is characterized by a decreased rate of ATP hydrolysis and $\mathrm{Ca}^{2+}$ transport (Lytton et al. 1992). Both mRNA and protein of SERCA2a and SERCA2b are present in fully differentiated VSMC. The amount of SERCA2a mRNA rises with age in parallel with the increase of smooth muscle $\alpha$-actin, which is a marker of VSMC, whereas the amount of SERCA2b mRNA remains constant (Le Jemtel et al. 1993). During the dedifferentiation there is a decrease of SERCA2a mRNA (Vallot et al. 2000), while the expression of SERCA2b remains unchanged (Lipskaia et al. 2005). Other studies reported the increase of SERCA2b expression during VSMC proliferation, whereas the expression of SERCA2a remains unaltered (Berra-Romani et al. 2008). In both cases there is a reduction in the ratio between a more efficient SERCA2 $a$ and a less efficient SERCA2b. The long-term elevation of $\left[\mathrm{Ca}^{2+}\right]_{i}$ is necessary for calcineurin activation and this is prevented by elevated SERCA2a activity (Bobe et al. 2011). Calcineurin dephosphorylates further proteins including nuclear factor of activated T-cells (NFAT) which enters into the cell nucleus and induces the expression of genes of proliferative phenotype. In addition, the elevated SERCA2a activity prevents pronounced $\mathrm{Ca}^{2+}$ depletion of sarcoplasmic reticulum which is an important component of SOC activation (Bobe et al. 2011).

\section{Calcium sensitization}

Calcium sensitization, which seems to be independent of $\mathrm{Ca}^{2+}$, is based upon the inhibition of MLCP (Fig. 1). There are two basic components of MLCP inhibition leading to calcium sensitization phosphorylation of regulatory MLCP subunit (MYPT1) and phosphorylation of smooth muscle-specific MLCP inhibiting protein CPI-17, the phosphorylated form of which is bound to MLCP, leading thus to its inhibition (Eto et al. 2004). Rho-kinase (ROCK) is responsible for the phosphorylation of both proteins MYPT1 and CPI-17 (Feng et al. 1999, Kureishi et al. 1997). CPI-17 is also intensively phosphorylated by protein kinase $\mathrm{C}$ (Dimopoulos et al. 2007). The inhibitory effect of ROCK on MLCP is counteracted by MLCP activation through cGMP action (Bolz et al. 2003). Besides MLCP inhibition ROCK also participates in $\left[\mathrm{Ca}^{2+}\right]_{\mathrm{i}}$ rise, which is independent of L-VDCC and internal $\mathrm{Ca}^{2+}$ stores, but seems to be mediated by ROCK influence on ROC channels activated through extracellular ligands (Ghisdal et al. 2003, Kureishi et al. 1997). $\mathrm{Ca}^{2+}$ signaling in VSMC is usually associated with the activation of $\mathrm{G}_{\mathrm{q} / 11} \alpha$ subunit of heterotrimeric $\mathrm{G}$ proteins (Wu et al. 1992), whereas the activation of small GTPase RhoA and $\mathrm{Ca}^{2+}$ sensitization are associated with the stimulation of $\mathrm{G}_{12 / 13} \quad \alpha$ subunit (Suzuki et al. 2003). Some vasoconstrictors (e.g. angiotensin II or endothelin-1) stimulate not only the receptors coupled with $G_{q / 11}$ but also the receptors coupled with $\mathrm{G}_{12 / 13}$ (Gohla et al. 2000), whereas norepinephrine stimulates $\alpha_{1}$ - and $\alpha_{2}$-adrenoceptors coupled to $\mathrm{G}_{\mathrm{q}^{\prime} 11}$ and $\mathrm{G}_{\mathrm{i}}$ proteins (Docherty 1998). This suggests a cooperation of $\mathrm{Ca}^{2+}$ signaling and $\mathrm{Ca}^{2+}$ sensitization. The phosphorylation of myosin light chain is necessary also for the migration and cytokinesis of dedifferentiated VSMC (Fukata et al. 2001). During the cultivation of aortic VSMC there is a relative reduction in 
the expression of some proteins specific for contractile phenotype ( $\alpha$-actin, myosin heavy chain, h-caldesmon, h1-calponin) while the expression of other proteins is augmented (RhoA, ROCK and MYPT1) (Woodsome et al. 2006). ROCK participates in the processes linked to the proliferation of dedifferentiated VSMC (Yamakawa et al. 2000).
Our recent data (Behuliak et al. 2015) suggest that a decreased expression in CPI-17 might be a cause of reduced $\mathrm{Ca}^{2+}$ sensitization in SHR, although enhanced phosphorylation of CPI-17 might partially counteract the functional significance of this alteration in RhoA/Rho kinase pathway.

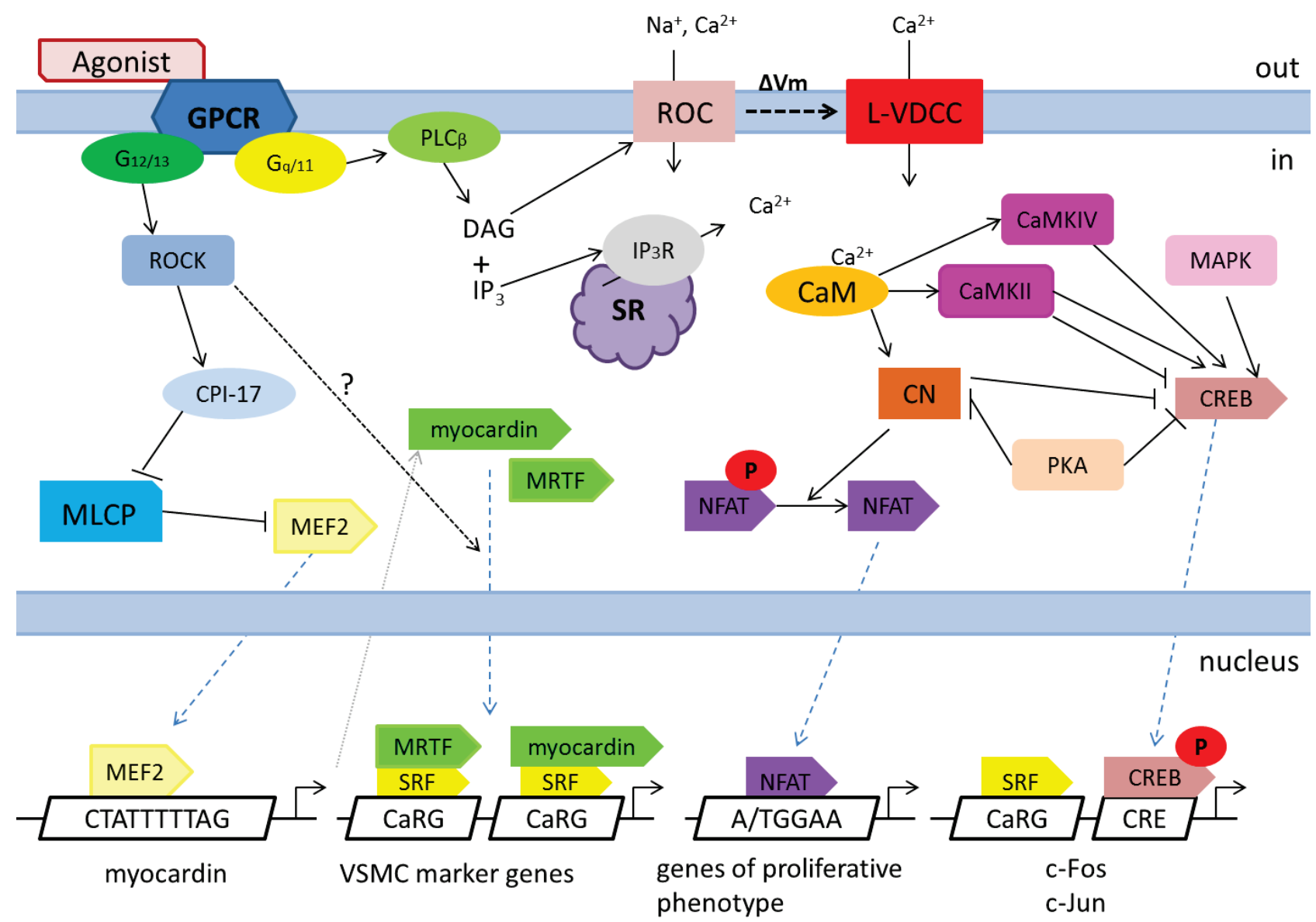

Fig. 2. Excitation-transcription coupling. Vasoconstrictors (such as norepinephrine, endothelin-1, angiotensin II) are acting on receptors coupled with $\mathrm{G}$ proteins (GPCR). Stimulation of these receptors leads to the activation heterotrimeric $\mathrm{G}$ proteins, which transmit the signal to further components of the respective cascade, leading thus to gene transcription. Rho-kinase (ROCK) phosphorylates CPI-17, which inhibits myosin light chain phosphatase (MLCP), interrupting thus its repressive action on myocytespecific enhancer factor 2 (MEF2). Transcription factor MEF2 is thereafter translocated to the nucleus, where it activates myocardin transcription. As a consequence of Rho-kinase action myocardin and myocardin-related transcription factors (MRTF) are translocated to the nucleus, where they are bound to serum response factor (SRF) and augment the transcription of genes characteristic for differentiated phenotype. $\left[\mathrm{Ca}^{2+}\right]_{\mathrm{i}}$ elevation leads to the activation of calmodulin (CaM), which activates calcineurin (CN). CN dephosphorylates transcription factor NFAT (nuclear factor of activated T-cells), that is thereafter translocated into the nucleus to activate the expression of genes of proliferative phenotype. Transcription factor CREB (CAMP responsive element binding protein) might by phosphorylated by various kinases with different effects on CREB activity. Activated CREB is bound on CRE element of gene promoter and together with SRF bound on CaRG element they activate transcription of c-Fos and c-Jun genes. Further abbreviations: $\mathrm{CaMK}-\mathrm{Ca}^{2+}$-calmodulin-dependent protein kinase; MAPK - mitogen-activated protein kinase. For other abbreviations see Figure 1.

\section{Excitation-Transcription Coupling}

The changes of VSMC phenotype positively correlate with the changes in gene profile expressed by a given cell. Excitation-transcription coupling is a process highly dependent on $\left[\mathrm{Ca}^{2+}\right]_{\mathrm{i}}$. Specific stimuli may activate various transcription factors depending on extracelullar and intracelullar conditions of the cells. Thus, under various conditions the same agonist might elicit different transcriptional responses; similarly the 
different agonists might cause the identical response (divergence and convergence of excitation and transcription coupling) (for details see Fig. 2).

\section{Serum response factor (SRF)}

The transcription of most marker genes of differentiated phenotype (smooth muscle $\alpha$-actin, myosin heavy chain, SM22 $\alpha$, telokin, desmin and h1-calponin) is dependent at least on a single CArG element localized in the gene promoter. CArG element is a 10-bp element with a sequence $\mathrm{CC}(\mathrm{A} / \mathrm{T})_{6} \mathrm{GG}$ on which $\mathrm{SRF}$ is bound (Miano 2003). Basic response of differentiated cells on the stimulation by fetal bovine serum (FBS) is the activation of early genes such as c-Fos. Proximal segment of c-Fos promoter is very sensitive to the stimulation with FBS. This element has the same motif as CArG and also binds SRF protein (Treisman 1992). Thus, SRF stimulates two opposite processes: differentiation and proliferation of VSMC. There are several possible explanations of this paradox. Marker genes of differentiated VSMC usually contain two CArG boxes, whereas c-Fos only one (Spencer and Misra 1996). In some marker genes of VSMC there are $\mathrm{C} / \mathrm{G}$ substitutions in $\mathrm{A} / \mathrm{T}$ rich region which lower the binding affinity of SRF (Hendrix et al. 2005). An interesting role can be played by myocardin, a highly potent SRF coactivator, the expression of which is increased after the induction of depolarization and $\mathrm{Ca}^{2+}$ entry into the cytosol, i.e. the state that corresponds to differentiated VSMC (Wamhoff et al. 2004). Myocardin stimulates CArG-dependent expression of marker genes of differentiated phenotype. Myocardin mRNA level decreases during vessel cultivation and the expression of marker genes of differentiated phenotype is reduced in parallel. In contrast, SRF level remains unchanged (Chen et al. 2002). On the other hand, after the vascular damage (Hendrix et al. 2005) or after PDGF application (Yoshida et al. 2007) there is a reduction of myocardin expression with simultaneous decrease in the expression of genes of the differentiated phenotype. Another interesting player seems to be Rho-kinase. Enhanced activation of RhoA stimulates the transcription of smooth muscle $\alpha$-actin, SM22 $\alpha$ and myosin heavy chain (Wamhoff et al. 2004). This is probably accomplished by a stimulation of the translocation of myocardin-related transcription factors (MRTF) into the nucleus (Miralles et al. 2003). MRTF and myocardin are associated with MADS-box of SRF and they participate in enhancing the target gene transcription (Pipes et al. 2006). Myocardin transcription is controlled by transcription factor MEF2 (myocytespecific enhancer factor 2) (Creemers et al. 2006). The expression of MEF2 and marker genes in VSMC is dependent on L-VDCC opening and the activation of ROCK (Ren et al. 2010). ROCK phosphorylates CPI-17, which binds to the catalytic subunit of MLCP, ending thus its repressive action on MEF2 protein activity (Pagiatakis et al. 2012).

Han et al. (2006) reported that SRF is involved on the control of the expression of smooth muscle MLCK (smMLCK) and phosphorylation of myosin light chain (MLC) through MAPK pathway (known also as Ras-RafMEK-ERK signal transduction cascade) which is upregulated in SHR (Touyz et al. 1999, Kubo et al. 2002). The inhibition of either SRF expression or Ras signaling considerably suppressed smMLCK expression in cultured VSMC of normotensive WKY rats (Han et al. 2006). SHR are characterized by a 12-base pair insertion adjacent to the CarG box which enhances SRF binding to smMLCK promoter resulting in enhanced smMLCK expression and phosphorylated MLC formation in SHR arteries (Han et al. 2006). Chronic in vivo inhibition of MEK (tyrosine/threonine kinase), which is increasing SRF occupancy of the smMLCK promoter, has similar blood pressure-lowering effects in SHR as chronic in vivo MLCK inhibition (Han et al. 2006). The upregulation MAPK/ERK pathway in stroke-prone SHR can be attenuated by chronic antihypertensive treatment by L-VDCC blocker amlodipine or by ACE inhibitor enalapril. Both antihypertensive drugs equally shifted VSMC phenotype towards the differentiated state by reducing nonmuscle myosin heavy chain NMHC/SMemb levels and elevating smooth muscle myosin heavy chain SM2 levels (Umemoto et al. 2006).

\section{cAMP responsive element binding protein (CREB)}

Transcription factor CREB is considered to be a regulator of VSMC quiescence (Klemm et al. 2001). Its aortic content is downregulated in numerous rodent models of hypertension, insulin resistance and diabetes (Watson et al. 2001, Schauer et al. 2010). CREB downregulation in the above mentioned models of cardiovascular diseases might be related to the action of oxidized LDL through the mechanisms involving reactive oxygen species formation and ERK activation (Schauer $e t$ al. 2010).

$\mathrm{Ca}^{2+}$-CaM-dependent enzymes are associated with both processes occurring during VSMC contraction or during transcription factor activation. Phosphorylation 
of CREB in the promoter is dependent on $\left[\mathrm{Ca}^{2+}\right]_{\mathrm{i}}$ (Pulver et al. 2004). $\mathrm{Ca}^{2+}-\mathrm{CaM}$ regulates $\mathrm{Ca}^{2+}-\mathrm{CaM}$-dependent protein kinase IV (CaMKIV) which activates CREB by its phosphorylation. Phosphorylated CREB is bound to CRE element in the promoter region regulating transcription of genes in both differentiated VSMC (Najwer and Lilly 2005) and proliferating VSMC (Cartin et al. 2000). CREB might be phosphorylated by several kinases on different sites and this enables the convergence of multiple signals. CREB is phosphorylated on serine 133 or 142. CaMKIV phosphorylates CREB on serine 133, whereas CaMKII phosphorylates serine 133 and 142. Phosphorylation of serine 142 positively correlates with CREB export from the nucleus (Liu et al. 2013) and functions here as a negative regulator of CREB activation. CaMK activity is dependent on $\left[\mathrm{Ca}^{2+}\right]_{i}$ and its changes may lead either to the enhancement or to the attenuation of cAMP ability to stimulate transcription depending on the specific CaMK form (Sun et al. 1994). Phosphorylation of serine 133 might be mediated by MAPK (Xing et al. 1996), cAMP-dependent protein kinase (PKA) (Dash et al. 1991) or other kinases. Phosphorylation by MAPK leads to the expression of c-Fos in cerebral arteries (Pulver-Kaste et al. 2006) and augments the proliferation and growth of aortic VSMC (Tokunou et al. 2001). The whole process can be inhibited by L-VDCC blockers. On the contrary, RyR opening in the membrane of sarcoplasmic reticulum decreases CREB phosphorylation. $\mathrm{Ca}^{2+}$ sparks elicited by RyR opening lead to $\mathrm{BK}_{\mathrm{Ca}}$ activation, membrane hyperpolarization and L-VDCC inactivation (Cartin et al. 2000). The application of CaMK inhibitor KN-62 lowers the expression of c-Jun which forms together with c-Fos a complex functioning as a transcription factor of early genes (Pagiatakis et al. 2012). The activation of CREB by means of PKA decreases proliferation and migration of pulmonary VSMC (Klemm et al. 2001). PKA stimulation leads to a formation of a repressor complex of MEF2 with histone deacetylase 4 and to a decrease in c-Jun expression (Gordon et al. 2009). Blood vessels from hypertensive rats have increased basal $\left[\mathrm{Ca}^{2+}\right]_{\mathrm{i}}$, activated CREB and higher c-Fos expression (Wellman et al. 2001). There is no general consensus on the description of signaling pathways leading to gene expression in VSMC with differentiated or proliferative phenotype. It seems that cellular response depends on the particular type of $\left[\mathrm{Ca}^{2+}\right]_{\mathrm{i}}$ change and the related activation of various intracellular kinases and phosphatases.
Nuclear factor of activated T-cells (NFAT)

NFAT is $\mathrm{Ca}^{2+}$-dependent transcription factor which is permanently expressed in VSMC. Its transcriptionally inactive phosphorylated form, which is present in cytosol, is activated by calcineurin the activation of which is triggered by VSMC excitation and $\left[\mathrm{Ca}^{2+}\right]_{\mathrm{i}}$ rise. Calcineurin-induced dephosphorylation modifies NFAT conformation and reveals its nuclear localization signal (Okamura et al. 2000). Activation of NFAT is negatively regulated by nuclear (Beals et al. 1997) and cytosolic kinases (Chow and Davis 2000, Zhu et al. 1998). NFAT4 is the main isoform in VSMC. $\mathrm{G}_{\mathrm{q} / 11}$ $\alpha$ subunit of heterotrimeric $\mathrm{G}$ proteins activates NFAT4 through $\left[\mathrm{Ca}^{2+}\right]_{\mathrm{i}}$ rise mediated by $\mathrm{IP}_{3} \mathrm{R}$ and L-VDCC. On the contrary, $\mathrm{BK}_{\mathrm{Ca}}$ activation attenuates the dephosphorylation of cytosolic NFAT4 via membrane hyperpolarization, $\mathrm{L}-\mathrm{VDCC}$ closure and $\left[\mathrm{Ca}^{2+}\right]_{\mathrm{i}}$ decrease (Stevenson et al. 2001). Activated NFAT4 also controls excitability of VSMC through the regulation of gene expression, namely by the decreased expression of voltage-dependent $\mathrm{K}^{+}$channel $\mathrm{K}_{\mathrm{v}} 2.1$ (Amberg et al. 2004). The application of $\alpha_{1}$-adrenergic agonist phenylephrine into the incubation medium has a chronic positive effect on VSMC proliferation. The activation of NFAT2 by calcineurin following $\left[\mathrm{Ca}^{2+}\right]_{\mathrm{i}}$ rise participates in this process (Pang and Sun 2009). Permanent SERCA2a activity leads to $\left[\mathrm{Ca}^{2+}\right]_{\mathrm{i}}$ reduction and to the inhibition of NFAT-induced VSMC proliferation (Lipskaia et al. 2005). The activation of NFAT is usually associated with the expression of genes characteristic for proliferative phenotype (Nilsson et al. 2007).

Calcineurin expression, which is enhanced during neointimal formation, is augmented in SHR compared to WKY rats (Takeda et al. 2008). It should be noted that chronic L-VDCC blockade by continuous nifedipine infusion suppresses the activation of calcineurin in SHR and this is associated with a reduction of cardiac hypertrophy and fibrosis in this hypertensive model (Zou et al. 2002). The regression of cardiac hypertrophy in SHR can also be induced by chronic inhibition of $\mathrm{Na}^{+} / \mathrm{H}^{+}$exchanger and this regression is accompanied by the inactivation of calcineurin/NFAT pathway (Ennis et al. 2007).

\section{VSMC alterations in hypertension}

Hypertension is associated with vascular wall remodeling (increased media/lumen ratio) in both human essential hypertension (EH) and genetic hypertension of 
the rat, although there is considerable difference between both species in the underlying structural changes. Human $\mathrm{EH}$ is characterized by inward remodeling without VSMC hypertrophy and/or proliferation, whereas increased VSMC mass was found in spontaneously hypertensive rats (SHR) (Mulvany 1992). It remains an open question whether these changes observed in the hypertensive subjects/animals are solely the consequence of their high blood pressure or whether they also participate in the pathogenesis of hypertension (Mulvany 1991, Folkow 1995).

Vascular wall hypertrophy (Folkow et al. 1973, Mulvany et al. 1978) in SHR is caused by VSMC hypertrophy (Owens and Schwartz 1982, Bucher et al. 1984) and/or hyperplasia (Head 1991, Devlin et al. 1995). Under the in vitro conditions VSMC derived from SHR proliferate faster than those originating from normotensive Wistar-Hyoto rats (Yamori et al. 1984, Hadrava et al. 1991, Saltis and Bobik 1992). Faster in vitro proliferation of VSMC and fibroblasts of SHR is associated with augmented responsiveness to various mitogens (Marche et al.1995). Although the mechanisms of this important strain difference are still not fully understood, many factors including enhanced expression of transforming growth factor beta (TGF- $\beta$ ) (Hadrava et al. 1991, Agrotis et al. 1995), hypernoradrenergic innervation (Head 1991) and increased vascular formation of angiotensin II (Mizuno et al. 1991, Fukuda et al. 1999) or endothelin-1 (Atef and Anand-Srivastava 2014) were proposed to be involved in the above vascular abnormalities of SHR.

There are numerous abnormalities in the contractile function of vascular smooth muscle in the resistance arteries of SHR (for review see Packer 1994, Hughes and Bund 2002, Pintérová et al. 2011). These abnormalities, which are responsible for enhanced arterial contraction of genetically hypertensive rats, include greater $\mathrm{Ca}^{2+}$ entry through voltage-dependent and/or receptor-operated $\mathrm{Ca}^{2+}$ channels (Bruner et al. 1986a,b) with a subsequent increase of potassium efflux through $\mathrm{Ca}^{2+}$-activated $\mathrm{K}^{+}$channels (Rinaldi and Bohr 1988). Augmented $\mathrm{Ca}^{2+}$ entry through L-VDCC (Wilde et al. 1994) seems to be a dominant alteration of cell calcium handling in genetic hypertension (Tostes et al. 1997) which was confirmed in our studies focused on the role of the contribution of $\mathrm{Ca}^{2+}$ entry and $\mathrm{Ca}^{2+}$ sensitization to blood pressure maintenance in SHR (Behuliak et al. 2013, 2015). However, little attention has been paid to the question whether some functional abnormalities reported in SHR might be related to the augmented fraction of dedifferentiated VSMC in their arteries or not. The same is true for increased passive $\mathrm{Ca}^{2+}$ entry into VSMC of non-stimulated SHR arteries (Fitzpatrick and Szentivanyi 1980, Winquist and Bohr 1983). Thus, cell calcium handling in differentiated and dedifferentiated cells or normotensive or hypertensive animals would deserve a careful detailed investigation in the future. This task might be complicated by the fact that cell calcium handling might be different in large (conduit) and small (resistance) arteries (Storm et al. 1992).

\section{Conflict of Interest}

There is no conflict of interest.

\section{Acknowledgements}

This research was supported by the institutional support RVO 67985823 and by Ministry of Health of the Czech Republic grant 15-25396A.

\section{Abbreviations}

$\Delta \mathrm{Vm}$ - membrane potential change; ACE - angiotensin converting enzyme; CaM - calmodulin; CaMK $\mathrm{Ca}^{2+}$-calmodulin-dependent protein kinase; cAMP cyclic adenosine monophosphate; CICR - calciuminduced calcium release; $\mathrm{CN}$ - calcineurin; CPI-17 smooth muscle-specific inhibitory protein of MLCP; CREB - cAMP responsive element binding protein; DAG - diacylglycerol; ERK - extracellular signalregulated kinase; GAP - GTPase-activating protein; GDP - guanosine diphosphate; GEF - guanine nucleotide exchange factor; GPCR - G protein-coupled receptors; GTP - guanosine triphosphate; $\mathrm{IP}_{3}$ - inositol-1,4, 5-trisphosphate; $\quad \mathrm{IP}_{3} \mathrm{R} \quad$-inositol-1,4,5-trisphosphate receptor; LDL - low-density lipoprotein; L-VDCC voltage-dependent $\mathrm{Ca}^{2+}$ channels; MAPK - mitogenactivated protein kinase; MEF2 - myocyte-specific enhancer factor 2; MEK - tyrosine/threonine kinase; MLC - myosin light chain; MLCK - myosin light chain kinase; MLCP - myosin light chain phosphatase; MRTF - myocardin-related transcription factors; NFAT nuclear factor of activated T-cells; Orai - pore forming subunit; PDGF - platelet-derived growth factor; PKC protein kinase $\mathrm{C} ; \mathrm{PLC}_{\beta}-$ phospholipase $\mathrm{C}_{\beta}$; RhoA GTPase of Ras homologue gene family; ROC - receptoroperated channels; ROCK - Rho-associated protein kinase; RyR - ryanodine receptors; SERCA - $\mathrm{Ca}^{2+}$ ATPase of the sarcoplasmic reticulum; SHR spontaneously hypertensive rat; SOC - store-operated 
channels; SR - sarcoplasmic reticulum; SRF - serum response factor; STIM1 - stromal interaction molecule 1; TGF- $\beta$ - transforming growth factor $\beta$; TRPC - transient receptor potential canonic channels; VSMC - vascular smooth muscle cells; WKY - Wistar-Kyoto rat.

\section{References}

ADEBIYI A, THOMAS-GATEWOOD CM, LEO MD, KIDD MW, NEEB ZP, JAGGAR JH: An elevation in physical coupling of type 1 inositol 1,4,5-trisphosphate ( $\left.\mathrm{IP}_{3}\right)$ receptors to transient receptor potential 3 (TRPC3) channels constricts mesenteric arteries in genetic hypertension. Hypertension 60: 1213-1219, 2012.

AFROZE T, SADI A, MOMEN MA, GU S, HEXIMER S, HUSAIN M: c-Myb-dependent inositol 1,4,5-trisphosphate receptor type-1 expression in vascular smooth muscle cells. Arterioscler Thromb Vasc Biol 27: 1305-1311, 2007.

AGROTIS A, SALTIS J, DILLEY R, BRAY P, BOBIK A: Transforming growth factor-beta 1 and the development of vascular hypertrophy in hypertension. Blood Press 4 (Suppl 2): 43-48, 1995.

ALBERT AP, LARGE WA: Activation of store-operated channels by noradrenaline via protein kinase $\mathrm{C}$ in rabbit portal vein myocytes. J Physiol 544: 113-125, 2002.

AMBERG GC, ROSSOW CF, NAVEDO MF, SANTANA LF: NFATc3 regulates Kv2.1 expression in arterial smooth muscle. J Biol Chem 279: 47326-47334, 2004.

ATEF ME, ANAND-SRIVASTAVA MB: Enhanced expression of Gq $\alpha$ and PLC- $\beta 1$ proteins contributes to vascular smooth muscle cell hypertrophy in SHR: role of endogenous angiotensin II and endothelin-1. Am J Physiol Cell Physiol 307: C97-C106, 2014.

BAČÁKOVÁ L, KUNEŠ J: Gender differences in growth of vascular smooth muscle cells isolated from hypertensive and normotensive rats. Clin Exp Hypertens 22: 33-44, 2000.

BAKKER ENTP, MEULEN ET, SPAAN JAE, VANBAVEL E: Organoid culture of cannulated rat resistance arteries: effect of serum factors on vasoactivity and remodeling. Am J Physi Heart Circ Physiol 278: H1233-H1240, 2000.

BAKKER ENTP, MEULEN ET, BERG BM, EVERTS V, ET AL: Inward remodeling follows chronic vasoconstriction in isolated resistance arteries. J Vasc Res 39: 12-20, 2002.

BAKKER ENTP, MATLUNG HL, BONTA P, VRIES CJ, ROOIJEN N, VANBAVEL E: Blood flow-dependent arterial remodelling is facilitated by inflammation but directed by vascular tone. Cardiovasc Res 78: 341-348, 2008.

BEALS CR, SHERIDAN CM, TURCK CW, GARDNER P, CRABTREE GR: Nuclear export of NF-ATc enhanced by glycogen synthase kinase-3. Science 275: 1930-1933, 1997.

BEHULIAK M, PINTÉROVÁ M, BENCZE M, PETROVÁ M, LISSSKOVÁ S, KAREN P, KUNEŠ J, VANĚČKOVÁ I, ZICHA J: $\mathrm{Ca}^{2+}$ sensitization and $\mathrm{Ca}^{2+}$ entry in the control of blood pressure and adrenergic vasoconstriction in conscious Wistar-Kyoto and spontaneously hypertensive rats. J Hypertens 31: 2025-2035, 2013.

BEHULIAK M, VAVŘÍNOVÁ A, BENCZE M, POLGÁROVÁ K, ERGANG P, KUNEŠ J, VANĚČKOVÁ I, ZICHA $\mathrm{J}$ : Ontogenetic changes in contribution of calcium sensitization and calcium entry to blood pressure maintenance of Wistar-Kyoto and spontaneously hypertensive rats. J Hypertens 33: 2443-2454, 2015.

BENDECK MP, ZEMPO N, CLOWES AW, GALARDY RE, REIDY MA: Smooth muscle cell migration and matrix metalloproteinase expression after arterial injury in the rat. Circ Res 75: 539-545, 1994.

BERGDAHL A, GOMEZ MF, WIHLBORG AK, ERLINGE D, EYJOLFSON A, XU SZ, BEECH DJ, DREJA K, HELLSTRAND P: Plasticity of TRPC expression in arterial smooth muscle: correlation with store-operated $\mathrm{Ca}^{2+}$ entry. Am J Physiol Cell Physiol 288: C872-C880, 2005.

BERRA-ROMANI R, MAZZOCCO-SPEZZIA A, PULINA MV, GOLOVINA VA: $\mathrm{Ca}^{2+}$ handling is altered when arterial myocytes progress from a contractile to a proliferative phenotype in culture. Am J Physiol Cell Physiol 295: C779-C790, 2008.

BERRIDGE MJ: Inositol trisphosphate and calcium signaling. Nature 361: 315-325, 1993.

BERRIDGE MJ: Elementary and global aspects of calcium signalling. J Physiol 499: 291-306, 1997. 
BERRIDGE MJ, BOOTMAN MD, RODERICK HL: Calcium signalling: dynamics, homeostasis and remodelling. Nat Rev Mol Cell Biol 4: 517-529, 2003.

BOBE R, HADRI L, LOPEZ JJ, SASSI Y, ATASSI F, KARAKIKES I, LIANG L, LIMON I, LOMPRE AM, HATEM, SN, HAJJAR RJ, LIPSKAIA L: SERCA2a controls the mode of agonist-induced intracellular $\mathrm{Ca}^{2+}$ signal, transcription factor NFAT and proliferation in human vascular smooth muscle cells. $J$ Mol Cell Cardiol 50: 621-633, 2011.

BOLZ SS, VOGEL L, SOLLINGER D, DERWAND R, DE WIT C, LOIRAND G, POHL U: Nitric oxide-induced decrease in calcium sensitivity of resistance arteries is attributable to activation of the myosin light chain phosphatase and antagonized by the RhoA/Rho kinase pathway. Circulation 107: 3081-3087, 2003.

BOOTMAN MD, BERRIDGE MJ: Subcellular $\mathrm{Ca}^{2+}$ signals underlying waves and graded responses in HeLa cells. Curr Biol 6: 855-865, 1996.

BRUNER CA, MYERS JH, SING CF, JOKELAINEN PT, WEBB RC: Genetic association of hypertension and vascular changes in stroke-prone spontaneously hypertensive rats. Hypertension 8: 904-910, 1986b.

BRUNER CA, MYERS JH, SING CF, JOKELAINEN PT, WEBB RC: Genetic basis for altered vascular responses to ouabain and potassium-free solution in hypertension. Am J Physiol 251: H1276-H1282, 1986a.

BUCHER B, TRAVO P, STOCLET JC: Smooth muscle cell hypertrophy and hyperplasia in the thoracic aorta of spontaneously hypertensive rats. Cell Biol Int Rep 8: 567-577, 1984.

BURRIDGE K, WENNERBERG K: Rho and Rac take center stage. Cell 116: 167-179, 2004.

BUUS CL, POURAGEAUD F, FAZZI GE, JANSSEN G, MULVANY MJ, DE MEY JGR: Smooth muscle cell changes during flow-related remodeling of rat mesenteric resistance arteries. Circ Res 89: 180-186, 2001.

CARTIN L, LOUNSBURY KM, NELSON MT: Coupling of $\mathrm{Ca}^{2+}$ to CREB activation and gene expression in intact cerebral arteries from mouse - Roles of ryanodine receptors and voltage-dependent $\mathrm{Ca}^{2+}$ channels. Circ Res 86: 760-767, 2000.

CATTERALL WA: Structure and regulation of voltage-gated $\mathrm{Ca}^{2+}$ channels. Annu Rev Cell Dev Biol 16: 521-555, 2000.

CHAABANE C, OTSUKA F, VIRMANI R, BOCHATON-PIALLAT M-L: Biological responses in stented arteries. Cardiovasc Res 99: 353-363, 2013.

CHEN J, KITCHEN CM, STREB JW, MIANO JM: Myocardin: a component of a molecular switch for smooth muscle differentiation. J Mol Cell Cardiol 34: 1345-1356, 2002.

CHEN J, WU J, LI L, ZOU Y-Z, ZHU D-L, GAO P-J: Effect of an acute mechanical stimulus on aortic structure in the transverse aortic constriction mouse model. Clin Exp Pharmacol Physiol 38: 570-576, 2011.

CHOW C W, DAVIS RJ: Integration of calcium and cyclic AMP signaling pathways by 14-3-3. Mol Cell Biol 20: 702$712,2000$.

CLOWES AW, CLOWES MM, KOCHER O, ROPRAZ P, CHAPONNIER C, GABBIANI G: Arterial smooth muscle cells in vivo: relationship between actin isoform expression and mitogenesis and their modulation by heparin. J Cell Biol 107: 1939-1945, 1988.

COX RH, RUSCH NJ: New expression profiles of voltage-gated ion channels in arteries exposed to high blood pressure. Microcirculation 9: 243-257, 2002.

CREEMERS EE, SUTHERLAND LB, MCANALLY J, RICHARDSON JA, OLSON EN: Myocardin is a direct transcriptional target of Mef2, Tead and Foxo proteins during cardiovascular development. Development 133: 4245-4256, 2006.

DASH PK, KARL KA, COLICOS MA, PRYWES R, KANDEL ER: cAMP response element-binding protein is activated by $\mathrm{Ca}^{2+} /$ calmodulin-dependent as well as camp-dependent protein-kinase. Proc Natl Acad Sci USA 88: 5061-5065, 1991.

DE CHAMPLAIN J: Pre- and postsynaptic adrenergic dysfunctions in hypertension. J Hypertens 8 (Suppl 7): S77-S85, 1990.

DEVLIN AM, DAVIDSON AO, GORDON JF, CAMPBELL AM, MORTON JJ, REID JL, DOMINICZAK AF: Vascular smooth muscle polyploidy in genetic hypertension: the role of angiotensin II. $J$ Hum Hypertens 9: 497-500, 1995. 
DIMOPOULOS GJ, SEMBA S, KITAZAWA K, ETO M, KITAZAWA T: $\mathrm{Ca}^{2+}$ dependent rapid $\mathrm{Ca}^{2+}$ sensitization of contraction in arterial smooth muscle. Circ Res 100: 121-129, 2007.

DOCHERTY JR: Subtypes of functional $\alpha_{1}$ - and $\alpha_{2}$-adrenoceptors. Eur J Pharmacol 361: 1-15, 1998.

ENNIS IL, GARCIARENA CD, ESCUDERO EM, PÉREZ NG, DULCE RA, CAMILIÓN DE HURTADO MC, CINGOLANI HE: Normalization of the calcineurin pathway underlies the regression of hypertensive hypertrophy induced by $\mathrm{Na}^{+} / \mathrm{H}^{+}$exchanger-1 (NHE-1) inhibition. Can J Physiol Pharmacol 85: 301-310, 2007.

EPSTEIN FH, GIBBONS GH, DZAU VJ: The emerging concept of vascular remodeling. $N$ Engl J Med 330: 14311438, 1994.

ETO M, KITAZAWA T, BRAUTIGAN DL: Phosphoprotein inhibitor CPI-17 specificity depends on allosteric regulation of protein phosphatase-1 by regulatory subunits. Proc Natl Acad Sci USA 101: 8888-8893, 2004.

FELLNER SK, ARENDSHORST WJ: Store-operated $\mathrm{Ca}^{2+}$ entry is exaggerated in fresh preglomerular vascular smooth muscle cells of SHR. Kidney Int 61: 2132-2141, 2002.

FENG JH, ITO M, ICHIKAWA K, ISAKA N, NISHIKAWA M, HARTSHORNE DJ, NAKANO T: Inhibitory phosphorylation site for Rho-associated kinase on smooth muscle myosin phosphatase. J Biol Chem 274: 37385-37390, 1999.

FITZPATRICK DF, SZENTIVANYI A: The relationship between increased myogenic tone and hyporesponsiveness in vascular smooth muscle of spontaneously hypertensive rats. Clin Exp Hypertens 2: 1023-1037, 1980.

FOLKOW B: Hypertensive structural changes in systemic precapillary resistance vessels: how important are they for in vivo haemodynamics? J Hypertens 13: 1546-1559, 1995.

FOLKOW B, HALLBÄCK M, LUNDGREN Y, SIVERTSSON R, WEISS L: Importance of adaptive changes in vascular design for establishment of primary hypertension, studied in man and in spontaneously hypertensive rats. Circ Res 32 (Suppl I): I2-I16, 1973.

FUKATA Y, AMANO M, KAIBUCHI K: Rho-Rho-kinase pathway in smooth muscle contraction and cytoskeletal reorganization of non-muscle cells. Trends Pharmacol Sci 22: 32-39, 2001.

FUKUDA N, SATOH C, HU WY, SOMA M, KUBO A, KISHIOKA H, WATANABE Y, IZUMI Y, KANMATSUSE K: Production of angiotensin II by homogeneous cultures of vascular smooth muscle cells from spontaneously hypertensive rats. Arterioscler Thromb Vasc Biol 19: 1210-1217, 1999.

GHISDAL P, VANDENBERG G, MOREL N: Rho-dependent kinase is involved in agonist-activated calcium entry in rat arteries. $J$ Physiol 551: 855-867, 2003.

GIACHINI FR, CHIAO CW, CARNEIRO FS, LIMA VV, CARNEIRO ZN, DORRANCE AM, TOSTES RC, WEBB RC: Increased activation of stromal interaction molecule-1/Orai-1 in aorta from hypertensive rats: a novel insight into vascular dysfunction. Hypertension 53: 409-416, 2009.

GIACHINI FR, LIMA VV, FILGUEIRA FP, DORRANCE AM, CARVALHO MH, FORTES ZB, WEBB RC, TOSTES RC: STIM1/Orai1 contributes to sex differences in vascular responses to calcium in spontaneously hypertensive rats. Clin Sci (Lond) 122: 215-226, 2012.

GOHLA A, SCHULTZ G, OFFERMANNS S: Role for $\mathrm{G}_{12} / \mathrm{G}_{13}$ in agonist-induced vascular smooth muscle cell contraction. Circ Res 87: 221-227, 2000.

GOLLASCH M, HAASE H, RIED C, LINDSCHAU C, MORANO I, LUFT FC, HALLER H: L-type calcium channel expression depends on the differentiated state of vascular smooth muscle cells. FASEB J 12: 593-601, 1998.

GORDON JW, PAGIATAKIS C, SALMA J, DU M, ANDREUCCI JJ, ZHAO JZ, HOU GP, PERRY RL, DAN QH, COURTMAN D, BENDECK MP, MCDERMOTT JC: Protein kinase A-regulated assembly of a MEF2.HDAC4 repressor complex controls c-Jun expression in vascular smooth muscle cells. $J$ Biol Chem 284: 19027-19042, 2009.

HAAS TL, DOYLE JL, DISTASI MR, NORTON LE, SHERIDAN KM, UNTHANK JL: Involvement of MMPs in the outward remodeling of collateral mesenteric arteries. Am J Physiol Heart Circ Physiol 293: H2429-H2437, 2007.

HADRAVA V, KRUPPA U, RUSSO RC, LACOURCIÈRE Y, TREMBLAY J, HAMET P: Vascular smooth muscle cell proliferation and its therapeutic modulation in hypertension. Am Heart J 122: 1198-1203, 1991. 
HAN YJ, HU WY, CHERNAYA O, ANTIC N, GU L, GUPTA M, PIANO M, DE LANEROLLE P: Increased myosin light chain kinase expression in hypertension: Regulation by serum response factor via an insertion mutation in the promoter. Mol Biol Cell 17: 4039-4050, 2006.

HELLIWELL RM, LARGE WA: $\alpha_{1}$-adrenoceptor activation of a non-selective cation current in rabbit portal vein by 1,2-diacyl-sn-glycerol. J Physiol 499: 417-428, 1997.

HEAD RJ: Hypernoradrenergic innervation: its relationship to functional and hyperplastic changes in the vasculature of the spontaneously hypertensive rat. Blood Vessels 26: 1-20, 1989.

HEAD RJ: Hypernoradrenergic innervation and vascular smooth muscle hyperplastic change. Blood Vessels 28: 173$178,1991$.

HENDRIX JA, WAMHOFF BR, MCDONALD OG, SINHA S, YOSHIDA T, OWENS GK: 5' CArG degeneracy in smooth muscle $\alpha$-actin is required for injury-induced gene suppression in vivo. J Clin Invest 115: 418-427, 2005.

HERMSMEYER K: Differences of calcium channels in vascular muscle in hypertension. Am J Hypertens 4: 412S415S, 1991.

HUGHES JM, BUND SJ: Arterial myogenic properties of the spontaneously hypertensive rat. Exp Physiol 87: 527-534, 2002.

IHARA E, HIRANO K, HIRANO M, NISHIMURA J, NAWATA H, KANAIDE H: Mechanism of down-regulation of L-type $\mathrm{Ca}^{2+}$ channel in the proliferating smooth muscle cells of rat aorta. J Cell Biochem 87: 242-251, 2002.

ISHIKAWA T, HUME JR, KEEF KD: Regulation of $\mathrm{Ca}^{2+}$ channels by cAMP and cGMP in vascular smooth muscle cells. Circ Res 73: 1128-1137, 1993.

ISOTANI E, ZHI G, LAU KS, HUANG J, MIZUNO Y, PERSECHINI A, GEGUCHADZE R, KAMM KE, STULL JT: Real-time evaluation of myosin light chain kinase activation in smooth muscle tissues from a transgenic calmodulin-biosensor mouse. Proc Natl Acad Sci USA 101: 6279-6284, 2004.

ISPANOVIC E, HAAS TL: JNK and PI3K differentially regulate MMP-2 and MT1-MMP mRNA and protein in response to actin cytoskeleton reorganization in endothelial cells. Am J Physiol Cell Physiol 291: C579-C588, 2006.

KLEMM DJ, WATSON PA, FRID MG, DEMPSEY EC, SCHAACK J, COLTON LA, NESTEROVA A, STENMARK KR, REUSCH JE: cAMP response element-binding protein content is a molecular determinant of smooth muscle cell proliferation and migration. J Biol Chem 276: 46132-46141, 2001.

KUBO T, IBUSUKI T, CHIBA S, KAMBE T, FUKUMORI R: Altered mitogen-activated protein kinase activation in vascular smooth muscle cells from spontaneously hypertensive rats. Clin Exp Pharmacol Physiol 29: 537-543, 2002.

KUDRYAVTSEVA O, HERUM KM, DAM VS, STRAARUP MS, KAMAEV D, BOEDTKJER DM, MATCHKOV VV, AALKJAER C: Downregulation of L-type $\mathrm{Ca}^{2+}$ channel in rat mesenteric arteries leads to loss of smooth muscle contractile phenotype and inward hypertrophic remodeling. Am J Physiol Heart Circ Physiol 306: H1287-H1301, 2014.

KUGA T, KOBAYASHI S, HIRAKAWA Y, KANAIDE H, TAKESHITA A: Cell cycle-dependent expression of $\mathrm{L}$ - and T-Type $\mathrm{Ca}^{2+}$ currents in rat aortic smooth muscle cells in primary culture. Circ Res 79: 14-19, 1996.

KUREISHI Y, KOBAYASHI S, AMANO M, KIMURA K, KANAIDE H, NAKANO T, KAIBUCHI K, ITO M: Rhoassociated kinase directly induces smooth muscle contraction through myosin light chain phosphorylation. J Biol Chem 272: 12257-12260, 1997.

LE JEMTEL TH, LAMBERT F, LEVITSKY DO, CLERGUE M, ANGER M, GABBIANI G, LOMPRE AM: Agerelated-changes in sarcoplasmic-reticulum $\mathrm{Ca}^{2+}$-ATPase and $\alpha$-smooth muscle actin gene-expression in aortas of normotensive and spontaneously hypertensive rats. Circ Res 72: 341-348, 1993.

LEWIS SJ, BHOPATKAR MY, WALTON TM, BATES JN: Role of voltage-sensitive calcium-channels in nitric oxide-mediated vasodilation in spontaneously hypertensive rats. Eur J Pharmacol 528: 144-149, 2005.

LIAO Y, ERXLEBEN C, YILDIRIM E, ABRAMOWITZ J, ARMSTRONG DL, BIRNBAUMER L: Orai proteins interact with TRPC channels and confer responsiveness to store depletion. Proc Natl Acad Sci USA 104: 46824687, 2007. 
LIN XH, HONG HS, ZOU GR, CHEN LL: Upregulation of TRPC1/6 may be involved in arterial remodeling in rat. $J$ Surg Res 195: 334-343, 2015.

LINDSEY SH, SONGU-MIZE E: Stretch-induced TRPC4 downregulation is accompanied by reduced capacitative $\mathrm{Ca}^{2+}$ entry in WKY but not SHR mesenteric smooth muscle cells. Clin Exp Hypertens 32: 288-292, 2010.

LIPSKAIA L, LOMPRE AM: Alteration in temporal kinetics of $\mathrm{Ca}^{2+}$ signaling and control of growth and proliferation. Biol Cell 96: 55-68, 2004.

LIPSKAIA L, DEL MONTE F, CAPIOD T, YACOUBI S, HADRI L, HOURS M, HAJJAR R. J, LOMPRE AM: Sarco/endoplasmic reticulum $\mathrm{Ca}^{2+}$-ATPase gene transfer reduces vascular smooth muscle cell proliferation and neointima formation in the rat. Circ Res 97: 488-495, 2005.

LIPSKAIA L, KEUYLIAN Z, BLIRANDO K, MOUGENOT N, JACQUET A, ROUXEL C, SGHAIRI H, ELAIB Z, BLAISE R, ADNOT S, HAJJAR RJ, CHEMALY ER, LIMON I, BOBE R: Expression of sarco (endo) plasmic reticulum calcium ATPase (SERCA) system in normal mouse cardiovascular tissues, heart failure and atherosclerosis. BiochimBiophys Acta 1843: 2705-2718, 2014.

LIU D, YANG D, HE H, CHEN X, CAO T, FENG X, MA L, LUO Z, WANG L, YAN Z, ZHU Z, TEPEL M: Increased transient receptor potential canonical type 3 channels in vasculature from hypertensive rats. Hypertension 53: 70-76, 2009.

LIU H, XIONG Z, SPERELAKIS N: Cyclic nucleotides regulate the activity of L-type calcium channels in smooth muscle cells from rat portal vein. J Mol Cell Cardiol 29: 1411-1421, 1997.

LIU Y, SUN LY, SINGER DV, GINNAN R, SINGER HA: CaMKII delta-dependent inhibition of cAMP-response element-binding protein activity in vascular smooth muscle. J Biol Chem 288: 33519-33529, 2013.

LYTTON J, WESTLIN M, BURK SE, SHULL GE, MACLENNAN DH: Functional comparisons between isoforms of the sarcoplasmic or endoplasmic-reticulum family of calcium pumps. J Biol Chem 267: 14483-14489, 1992.

MARCHE P, HEREMBERT T, ZHU DL: Molecular mechanisms of vascular hypertrophy in the spontaneously hypertensive rat. Clin Exp Pharmacol Physiol 22 (Suppl 1): S114-S116, 1995.

MATCHKOV VV, KUDRYAVTSEVA O, AALKJAER C: Intracellular $\mathrm{Ca}^{2+}$ signalling and phenotype of vascular smooth muscle cells. Basic Clin Pharmacol Toxicol 110: 42-48, 2012.

MIANO JM: Serum response factor: toggling between disparate programs of gene expression. $J$ Mol Cell Cardiol 35: 577-593, 2003.

MIRALLES F, POSERN G, ZAROMYTIDOU AI, TREISMAN R: Actin dynamics control SRF activity by regulation of its coactivator MAL. Cell 113: 329-342, 2003.

MIZUNO K, TANI M, NIIMURA S, FUKUCHI S: Effect of delapril on the vascular angiotensin II release in isolated hind legs of the spontaneously hypertensive rat: evidence for potential relevance of vascular angiotensin II to the maintenance of hypertension. Clin Exp Pharmacol Physiol 18: 619-625, 1991.

MULVANY MJ: Are vascular abnormalities a primary cause or secondary consequence of hypertension? Hypertension 18 (Suppl I): I52-I57, 1991.

MULVANY MJ: The development and regression of vascular hypertrophy. J Cardiovasc Pharmacol 19 (Suppl 2): S22S27, 1992.

MULVANY MJ, HANSEN OK, AALKJAER C: Direct evidence that the greater contractility of resistance vessels in spontaneously hypertensive rats is associated with a narrowed lumen, a thickened media, and an increased number of smooth muscle cell layers. Circ Res 43: 854-864, 1978.

MUNOZ E, HERNANDEZ-MORALES M, SOBRADILLO D, ROCHER A, NUNEZ L, VILLALOBOS C: Intracellular $\mathrm{Ca}^{2+}$ remodeling during the phenotypic journey of human coronary smooth muscle cells. Cell Calcium 54: 375-385, 2013.

NAJWER I, LILLY B: $\mathrm{Ca}^{2+} /$ calmodulin-dependent protein kinase IV activates cysteine-rich protein 1 through adjacent CRE and CArG elements. Am J Physiol Cell Physiol 289: C785-C793, 2005.

NELSON MT, STANDEN MB, BRAYDEN JE, WORLEY JF: Noradrenaline contracts arteries by activating voltagedependent calcium channels. Nature 336: 382-385, 1988.

NELSON MT, CHENG H, RUBART M, SANTANA LF, BONEV AD, KNOT HJ, LEDERER WJ: Relaxation of arterial smooth-muscle by calcium sparks. Science 270: 633-637, 1995. 
NILSSON LM, SUN ZW, NILSSON J, NORDSTROM I, CHEN YW, MOLKENTIN JD, WIDE-SWENSSON D, HELLSTRAND P, LYDRUP ML, GOMEZ MF: Novel blocker of NFAT activation inhibits IL-6 production in human myometrial arteries and reduces vascular smooth muscle cell proliferation. Am J Physiol Cell Physiol 292: C1167-C1178, 2007.

NOORANI MM, NOEL RC, MARRELLI SP: Upregulated TRPC3 and downregulated TRPC1 channel expression during hypertension is associated with increased vascular contractility in rat. Front Physiol 2: 42, 2011.

OHYA Y, TSUCHIHASHI T, KAGIYAMA S, ABE I, FUJISHIMA M: Single L-type calcium channels in smooth muscle cells from resistance arteries of spontaneously hypertensive rats. Hypertension 31: 1125-1129, 1998.

OKAMURA H, ARAMBURU J, GARCIA-RODRIGUEZ C, VIOLA JP, RAGHAVAN A, TAHILIANI M, ZHAN XL, QIN J, HOGAN PG, RAO A: Concerted dephosphorylation of the transcription factor NFAT1 induces a conformational switch that regulates transcriptional activity. Mol Cell 6: 539-550, 2000.

ORLOV SN, TREMBLAY J, HAMET P: cAMP signaling inhibits dihydropyridine-sensitive $\mathrm{Ca}^{2+}$ influx in vascular smooth muscle cells. Hypertension 27: 774-780, 1996.

OWENS GK: Control of hypertrophic versus hyperplastic growth of vascular smooth muscle cells. Am J Physiol 257: H1755-H1765, 1989.

OWENS GK: Regulation of differentiation of vascular smooth muscle cells. Physiol Rev 75: 487-517, 1995.

OWENS GK, SCHWARTZ SM: Alterations in vascular smooth muscle mass in the spontaneously hypertensive rat. Role of cellular hypertrophy, hyperploidy, and hyperplasia. Circ Res 51: 280-289, 1982.

OWENS GK, SCHWARTZ SM: Vascular smooth muscle cell hypertrophy and hyperploidy in the Goldblatt hypertensive rat. Circ Res 53: 491-501, 1983.

OWENS GK, LOEB A, GORDON D, THOMPSON MM: Expression of smooth muscle-specific alpha-isoactin in cultured vascular smooth muscle cells: relationship between growth and cytodifferentiation. $J$ Cell Biol 102: 343-352, 1986.

OWENS GK, VERNON SM, MADSEN CS: Molecular regulation of smooth muscle cell differentiation. $J$ Hypertens 14 (Suppl 5): S55-S64, 1996.

OWENS GK, KUMAR MS, WAMHOFF BR: Molecular regulation of vascular smooth muscle cell differentiation in development and disease. Physiol Rev 84: 767-801, 2004.

PACKER CS: Changes in arterial smooth muscle contractility, contractile proteins, and arterial wall structure in spontaneous hypertension. Proc Soc Exp Biol Med 207: 148-174, 1994.

PAGIATAKIS C, GORDON JW, EHYAI S, MCDERMOTT JC: A Novel RhoA/ROCK-CPI-17-MEF2C signaling pathway regulates vascular smooth muscle cell gene expression. J Biol Chem 287: 8361-8370, 2012.

PANG X, SUN NL: Calcineurin-NFAT signaling is involved in phenylephrine-induced vascular smooth muscle cell proliferation. Acta Pharmacol Sin 30: 537-544, 2009.

PAULIS L, LÍŠKOVÁ S, PINTÉROVÁ M, DOBEŠOVÁ Z, KUNEŠ J, ZICHA J: Nifedipine-sensitive noradrenergic vasoconstriction is enhanced in spontaneously hypertensive rats: the influence of chronic captopril treatment. Acta Physiol (Oxford) 191: 255-266, 2007.

PEREZ-REYES E: Molecular physiology of low-voltage-activated T-type calcium channels. Physiol Rev 83: 117-161, 2003.

PESIC A, MADDEN JA, PESIC M, RUSCH NJ: High blood pressure upregulates arterial L-type $\mathrm{Ca}^{2+}$ channels: is membrane depolarization the signal? Circ Res 94: e97-e104, 2004.

PINTÉROVÁ M, LÍŠKOVÁ S, DOBEŠOVÁ Z, BEHULIAK M, KUNEŠ J, ZICHA J: Impaired control of L-type voltage-dependent calcium channels in experimental hypertension. Physiol Res 58 (Suppl 2): S43-S54, 2009.

PINTÉROVÁ M, KAREN P, KUNEŠ J, ZICHA J: Role of nifedipine-sensitive sympathetic vasoconstriction in maintenance of high blood pressure in spontaneously hypertensive rats: effect of $\mathrm{G}_{\mathrm{i}}$-protein inactivation by pertussis toxin. J Hypertens 28: 969-978, 2010.

PINTÉROVÁ M, KUNEŠ J, ZICHA J: Altered neural and vascular mechanisms in hypertension. Physiol Res 60: 381$402,2011$.

PIPES GC, CREEMERS EE, OLSON EN: The myocardin family of transcriptional coactivators: versatile regulators of cell growth, migration, and myogenesis. Genes Dev 20: 1545-1556, 2006. 
POTIER M, GONZALEZ JC, MOTIANI RK, ABDULLAEV IF, BISAILLON JM, SINGER HA, TREBAK M: Evidence for STIM1-and Orai1-dependent store-operated calcium influx through I-CRAC in vascular smooth muscle cells: role in proliferation and migration. FASEB J 23: 2425-2437, 2009.

PRATT PF, BONNET S, LUDWIG LM, BONNET P, RUSCH NJ: Upregulation of L-type $\mathrm{Ca}^{2+}$ channels in mesenteric and skeletal arteries of SHR. Hypertension 40: 214-219, 2002.

PULINA MV, ZULIAN A, BERRA-ROMANI R, BESKINA O, MAZZOCCO-SPEZZIA A, BARYSHNIKOV SG, PAPPARELLA I, HAMLYN JM, BLAUSTEIN MP, GOLOVINA VA: Upregulation of $\mathrm{Na}^{+}$and $\mathrm{Ca}^{2+}$ transporters in arterial smooth muscle from ouabain-induced hypertensive rats. Am J Physiol Heart Circ Physiol 298: H263-H274, 2010.

PULVER RA, ROSE-CURTIS P, ROE MW, WELLMAN GC, LOUNSBURY KM: Store-operated $\mathrm{Ca}^{2+}$ entry activates the CREB transcription factor in vascular smooth muscle. Circ Res 94: 1351-1358, 2004.

PULVER-KASTE RA, BARLOW CA, BOND J, WATSON A, PENAR PL, TRANMER B, LOUNSBURY KM: $\mathrm{Ca}^{2+}$ source-dependent transcription of CRE-containing genes in vascular smooth muscle. Am J Physiol Heart Circ Physiol 291: H97-H105, 2006.

REN J, ALBINSSON S, HELLSTRAND P: Distinct effects of voltage- and store-dependent calcium influx on stretchinduced differentiation and growth in vascular smooth muscle. J Biol Chem 285: 31829-31839, 2010.

RINALDI G, BOHR D: Plasma membrane and its abnormalities in hypertension. Am J Med Sci 295: 389-395, 1988.

SALEH SN, ALBERT AP, PEPPIATT CM, LARGE WA: Angiotensin II activates two cation conductances with distinct TRPC1 and TRPC6 channel properties in rabbit mesenteric artery myocytes. $J$ Physiol 577: 479-495, 2006.

SALTIS J, BOBIK A: Vascular smooth muscle growth in genetic hypertension: evidence for multiple abnormalities in growth regulatory pathways. J Hypertens 10: 635-43, 1992.

SCHAUER IE, KNAUB LA, LLOYD M, WATSON PA, GLIWA C, LEWIS KE, CHAIT A, KLEMM DJ, GUNTER JM, BOUCHARD R, MCDONALD TO, O'BRIEN KD, REUSCH JE: CREB downregulation in vascular disease: a common response to cardiovascular risk. Arterioscler Thromb Vasc Biol 30: 733-741, 2010.

SCHOBER A: Chemokines in vascular dysfunction and remodeling. Arterioscler Thromb Vasc Biol 28: 1950-1959, 2008.

SHO E, SHO M, SINGH TM, NANJO H, KOMATSU M, XU CP, MASUDA H, ZARINS CK: Arterial enlargement in response to high flow requires early expression of matrix metalloproteinases to degrade extracellular matrix. Exp Mol Pathol 73: 142-153, 2002.

SMANI T, ZAKHAROV SI, CSUTORA P, LENO E, TREPAKOVA ES, BOLOTINA VM: A novel mechanism for the store-operated calcium influx pathway. Nat Cell Biol 6: 113-120, 2004.

SOMLYO AP, SOMLYO AV: $\mathrm{Ca}^{2+}$ sensitivity of smooth muscle and nonmuscle myosin II: Modulated by G proteins, kinases, and myosin phosphatase. Physiol Rev 83: 1325-1358, 2003.

SOMLYO AP, WU X, WALKER LA, SOMLYO AV: Pharmacomechanical coupling: the role of calcium, G-proteins, kinases and phosphatases. Rev Physiol Biochem Pharmacol 134: 201-234, 1999.

SONKUSARE S, PALADE PT, MARSH JD, TELEMAQUE S, PESIC A, RUSCH NJ: Vascular calcium channels and high blood pressure. pathophysiology and therapeutic implications. Vascul Pharmacol 44: 131-142, 2006.

SPENCER JA, MISRA RP: Expression of the serum response factor gene is regulated by serum response factor binding sites. J Biol Chem 271: 16535-16543, 1996.

STAICULESCU MC, GALIÑANES EL, ZHAO G, ULLOA U, JIN M, BEIG MI, MEININGER GA, MARTINEZLEMUS LA: Prolonged vasoconstriction of resistance arteries involves vascular smooth muscle actin polymerization leading to inward remodelling. Cardiovasc Res 98: 428-436, 2013.

STEVENSON AS, GOMEZ MF, HILL-EUBANKS DC, NELSON MT: NFAT4 movement in native smooth muscle. A role for differential $\mathrm{Ca}^{2+}$ signaling. J Biol Chem 276: 15018-15024, 2001.

STORM DS, STUENKEL EL, WEBB RC: Calcium channel activation in arterioles from genetically hypertensive rats. Hypertension 20: 380-388, 1992.

SUN PQ, ENSLEN H, MYUNG PS, MAURER RA: Differential activation of CREB by $\mathrm{Ca}^{2+} /$ calmodulin-dependent $^{2}$ protein kinases type II and type IV involves phosphorylation of a site that negatively regulates activity. Genes Dev 8: 2527-2539, 1994. 
SUZUKI N, NAKAMURA S, MANO H, KOZASA T: G 12 activates Rho GTPase through tyrosine-phosphorylated leukemia-associated RhoGEF. Proc Natl Acad Sci USA 100: 733-738, 2003.

TAI K, VANDENBERG G, HAMAIDE MC, WIBO M, MOREL N: Effect of organ culture on noradrenaline-evoked contraction, calcium signalling and TRPC expression in rat mesenteric artery. $J$ Vasc Res 46: 353-364, 2009.

TAKEDA R, SUZUKI E, TAKAHASHI M, OBA S, NISHIMATSU H, KIMURA K, NAGANO T, NAGAI R, HIRATA Y: Calcineurin is critical for sodium-induced neointimal formation in normotensive and hypertensive rats. Am J Physiol Heart Circ Physiol 294: H2871-H2878, 2008.

TOKUNOU T, ICHIKI T, TAKEDA K, FUNAKOSHI Y, IINO N, TAKESHITA A: cAMP response element-binding protein mediates thrombin-induced proliferation of vascular smooth muscle cells. Arterioscler Thromb Vasc Biol 21: 1764-1769, 2001.

TOSTES RC, WILDE DW, BENDHACK LM, WEBB RC: Calcium handling by vascular myocytes in hypertension. Braz J Med Biol Res 30: 315-323, 1997.

TOUYZ RM, EL MABROUK M, HE G, WU XH, SCHIFFRIN EL: Mitogen-activated protein/extracellular signalregulated kinase inhibition attenuates angiotensin II-mediated signaling and contraction in spontaneously hypertensive rat vascular smooth muscle cells. Circ Res 84: 505-515, 1999.

TREISMAN R: The serum response element. Trends Biochem Sci 17: 423-426, 1992.

TUTTLE JL, NACHREINER RD, BHULLER AS, CONDICT KW, CONNORS BA, HERRING BP, DALSING MC, UNTHANK JL: Shear level influences resistance artery remodeling: wall dimensions, cell density, and eNOS expression. Am J Physiol Heart Circ Physiol 281: H1380-H1389, 2001.

UMEMOTO S, KAWAHARA S, HASHIMOTO R, UMEJI K, MATSUDA S, TANAKA M, KUBO M, MATSUZAKI M: Different effects of amlodipine and enalapril on the mitogen-activated protein kinase/extracellular signalregulated kinase pathway for induction of vascular smooth muscle cell differentiation in vivo. Hypertens Res 29: 179-186, 2006.

VALLOT O, COMBETTES L, JOURDON P, INAMO J, MARTY I, CLARET M, LOMPRE AM: Intracellular $\mathrm{Ca}^{2+}$ handling in vascular smooth muscle cells is affected by proliferation. Arterioscler Thromb Vasc Biol 20: 1225$1235,2000$.

WAMHOFF BR, BOWLES DK, MCDONALD OG, SINHA S, SOMLYO AP, SOMLYO AV, OWENS GK: L-type voltage-gated $\mathrm{Ca}^{2+}$ channels modulate expression of smooth muscle differentiation marker genes via a Rho kinase/myocardin/SRF-dependent mechanism. Circ Res 95: 406-414, 2004.

WATSON PA, NESTEROVA A, BURANT CF, KLEMM DJ, REUSCH JE: Diabetes-related changes in cAMP response element-binding protein content enhance smooth muscle cell proliferation and migration. $J$ Biol Chem 276: 46142-46150, 2001.

WELLMAN GC, CARTIN L, ECKMAN DM, STEVENSON AS, SAUNDRY CM, LEDERER WJ, NELSON MT: Membrane depolarization, elevated $\mathrm{Ca}^{2+}$ entry, and gene expression in cerebral arteries of hypertensive rats. Am J Physiol Heart Circ Physiol 281: H2559-H2567, 2001.

WILDE DW, FURSPAN PB, SZOCIK JF: Calcium current in smooth muscle cells from normotensive and genetically hypertensive rats. Hypertension 24: 739-746, 1994.

WILKERSON MK, HEPPNER TJ, BONEV AD, NELSON MT: Inositol trisphosphate receptor calcium release is required for cerebral artery smooth muscle cell proliferation. Am J Physiol Heart Circ Physiol 290: H240H247, 2006.

WINQUIST RJ, BOHR DF: Structural and functional changes in cerebral arteries from spontaneously hypertensive rats. Hypertension 5: 292-297, 1983.

WOODSOME TP, POLZIN A, KITAZAWA K, ETO M, KITAZAWA T: Agonist- and depolarization-induced signals for myosin light chain phosphorylation and force generation of cultured vascular smooth muscle cells. $J$ Cell Sci 119: 1769-1780, 2006.

WU DQ, KATZ A, LEE CH, SIMON MI: Activation of phospholipase C by $\alpha_{1}$-adrenergic receptors is mediated by the a subunits of $\mathrm{G}_{\mathrm{q}}$ family. J Biol Chem 267: 25798-25802, 1992.

WU MM, BUCHANAN J, LUIK RM, LEWIS RS: $\mathrm{Ca}^{2+}$ store depletion causes STIM1 to accumulate in ER regions closely associated with the plasma membrane. J Cell Biol 174: 803-813, 2006. 
XI XP, GRAF K, GOETZE S, FLECK E, HSUEH WA, LAW RE: Central role of the MAPK pathway in Ang IImediated DNA synthesis and migration in rat vascular smooth muscle cells. Arterioscler Thromb Vasc Biol 19: 73-82, 1999.

XING J, GINTY DD, GREENBERG ME: Coupling of the RAS-MAPK pathway to gene activation by RSK2, a growth factor-regulated CREB kinase. Science 273: 959-963, 1996.

YAMAKAWA T, TANAKA S, NUMAGUCHI K, YAMAKAWA Y, MOTLEY ED, ICHIHARA S, INAGAMI T: Involvement of Rho-kinase in angiotensin II-induced hypertrophy of rat vascular smooth muscle cells. Hypertension 35: 313-318, 2000.

YAMORI Y, IGAWA T, TAGAMI M, KANBE T, NARA Y, KIHARA M, HORIE R: Humoral trophic influence on cardiovascular structural changes in hypertension. Hypertension 6 (Suppl III): III27-III32, 1984.

YOSHIDA T, GAN Q, SHANG YT, OWENS GK: Platelet-derived growth factor-BB represses smooth muscle cell marker genes via changes in binding of MKL factors and histone deacetylases to their promoters. Am J Physiol Cell Physiol 292: C886-C895, 2007.

YU Y, SWEENEY M, ZHANG S, PLATOSHYN O, LANDSBERG J, ROTHMAN A, YUAN JX: PDGF stimulates pulmonary vascular smooth muscle cell proliferation by upregulating TRPC6 expression. Am J Physiol Cell Physiol 284: C316-C330, 2003.

ZHU JY, SHIBASAKI F, PRICE R, GUILLEMOT JC, YANO T, DOTSCH V, WAGNER G, FERRARA P, MCKEON F: Intramolecular masking of nuclear import signal on NF-AT4 by casein kinase I and MEKK1. Cell 93: 851$861,1998$.

ZICHA J, DOBEŠOVÁ Z, BEHULIAK M, PINTÉROVÁ M, KUNEŠ J, VANĚČKOVÁ I: Nifedipinesensitive blood pressure component in hypertensive models characterized by high activity of either sympathetic nervous system or renin-angiotensin system. Physiol Res 63: 13-26, 2014.

ZOU Y, YAMAZAKI T, NAKAGAWA K, YAMADA H, IRIGUCHI N, TOKO H, TAKANO H, AKAZAWA H, NAGAI R, KOMURO I: Continuous blockade of L-type $\mathrm{Ca}^{2+}$ channels suppresses activation of calcineurin and development of cardiac hypertrophy in spontaneously hypertensive rats. Hypertens Res 25: 117-124, 2002.

ZULIAN A, BARYSHNIKOV SG, LINDE CI, HAMLYN JM, FERRARI P, GOLOVINA VA: Upregulation of $\mathrm{Na}^{+} / \mathrm{Ca}^{2+}$ exchanger and TRPC6 contributes to abnormal $\mathrm{Ca}^{2+}$ homeostasis in arterial smooth muscle cells from Milan hypertensive rats. Am J Physiol Heart Circ Physiol 299: H624-H633, 2010. 